\title{
artículos
}

\section{Elegía pintada. Los paisajes del retablo de Santa Bárbara de la Catedral de Málaga}

Susana E. Rodríguez de Tembleque García

Archivo Catedral de Málaga. Investigadora vinculada a la UMA

PALABRAS CLAVE: Pintura renacentista/ Iconología/ Catedral de Málaga

\section{RESUMEN}

El contenido escatológico de los paisajes del retablo de Santa Bárbara de la Catedral de Málaga avala la hipótesis de datación del siglo XVI. Las tablas manifiestan la influencia del humanista Juan de Valencia y del pintor italiano César Arbasia y constituyen una elegía que ensalza al canónigo Francisco del Pozo.

\section{ABSTRACT}

The scatological landscapes of the Saint Barbara altarpiece in the Malaga Cathedral support the hypothesis that these paintings are from the 16th century. The panels show the influence from Juan de Valencia, humanist, and Cesare Arbasia, the Italian painter. They are an elegy extolling the Canon Francisco del Pozo.

1. El ENIGMA DE LOS PAISAJES Y LAS HIPÓTESIS DE DATACIÓN.

Uno de los conjuntos artísticos muebles más destacados y bien conocidos en la Catedral de Málaga es, sin duda, el retablo de Santa Bárbara. No sólo en las descripciones ya denominadas clásicas y hoy convertidas en fuentes para la Historia, sino también en los trabajos más recientes de tipo académico y divulgativo, la importancia y valía del retablo más antiguo de la Catedral malagueña quedan siempre manifiestas.

A pesar de ello, todos los autores contemporáneos que profundizan en su descripción coinciden en destacar de manera especial uno de sus elementos, tanto por la calidad del mismo como por lo enigmático de su presencia: "En el sotobanco del retablo nos encontramos con unas representaciones paisajísticas en tabla que constituye uno de los elementos más interesantes del conjunto"1.

* RODRígueZ TEMBLEQUE, S .E.: "Elegía pintada. Los paisajes del Retablo de Santa Bárbara de la Catedral de Málaga", Boletín de Arte n² 28, Departamento de Historia del Arte, Universidad de Málaga, 2007 págs. 59-82. 
"Estos paisajes, de una exquisitez extrema, plantean una incógnita aún no resuelta"2

Hasta fechas relativamente recientes, en las descripciones del retablo se pasaba por alto la alusión al sotobanco del mismo y a su contenido. La razón más probable hay que buscarla, por un lado, en su ubicación, oculta durante siglos tras sacras, candelabros, cruces y objetos de culto y, por otra parte, en su lamentable estado de conservación: "Los paisajes del sotobanco presentaban un exagerado oscurecimiento total, más debido al humo de velas y a una gruesa capa de salpicaduras de cera ennegrecida, llegando a quemar algunas zonas. [...] También hay presencia de telas de araña y gran cantidad de goterones de cera fuertemente adheridos a la superficie inferior del retablo, [...] los paisajes del sotobanco son las zonas más afectadas por el deterioro"3.

Estas circunstancias lo llevaron a una inveterada invisibilidad 4 que fue desvelada por Lorenzo Pérez del Campo en 1985. Además de dar a conocer los datos fundamentales para el estudio del retablo de Santa Bárbara, el investigador elabora una primera hipótesis sobre los paisajes y su datación.

Si para el resto del retablo encontró cumplida explicación en cuanto a su contenido, fechas y autoría en el rescatado contrato que en 1524 establecieran el entallador Nicolás Tiller y el canónigo Francisco del Pozo, la ausencia en dicho documento de cualquier referencia a los paisajes del sotobanco le hizo plantear una lógica conclusión: "Entre el banco y el altar se colocan seis pequeñas tablitas con unas interesantes escenas paisajísticas, realizadas en la segunda mitad del siglo XVI con el fin de recrecer ligeramente el retablo a fin de adaptarlo convenientemente a su nueva ubicación en la capilla de la catedral renacentista" 5 .

Este retablo representa un testimonio fundamental de uno de los focos góticos que persistían en España en la primera mitad del siglo XVI6. Y tras el

1 HUERTAS MAMELY, A: "Retablo de Santa Bárbara",en SAURET GUERRERO, T. (dir.): Patrimonio Cultural de Málaga y su provincia, Málaga, CEDMA, 2000, pág. 36.

2 SAURET GUERRERO, T.: "Consideraciones en torno al fenómeno de la plástica en Málaga durante la Edad Moderna" en SAURET GUERRERO, T. (dir.): Op. Cit, pág. 21.

3 Archivo Catedral Málaga (A.C.M.). HASBACH LUGO, B.: Conservación y restauración del retablo de Santa Bárbara de la Catedral de Málaga, Noviembre de 1995-Octubre de 1996, Málaga, Junta de Andalucía, 1996.

4 Hasta el punto que el trabajo monográfico del profesor Agustín Clavijo sobre las pinturas de la Catedral de Málaga obvia cualquier referencia a los paisajes del sotobanco de un retablo, como éste, que describe y analiza en profundidad. Cfr. A.C.M., CLAVIJO GARCÍA, A.: Las pinturas de la Catedral de Málaga, Granada, Universidad, 1971. Memoria de licenciatura inédita.

5 PÉREZ DEL CAMPO, L.: "Nicolás Tiller y el Retablo de Santa Bárbara en la Catedral de Málaga", en Baética, $n^{\circ} 8,1985$, pág. 80

6 CAMON AZNAR, J.: Fernando el Católico y el arte español de su tiempo. Zaragoza, Institución Fernando el Católico, 1952, pág. 18 


\section{- E artículos Elegía pintada. Los paisajes del retablo de Santa Bárbara...}

análisis del contenido del contrato se plantean dos aspectos diferenciados: su ejecución, que corrió a cargo del escultor Tiller tanto para la arquitectura lignaria como para la imaginería, de Jacome Lobeo para la policromía y de Francisco de Ledesma para las pinturas de los guardapolvos; y su ubicación, pues sería contratado por el fundador de la Capilla de Santa Bárbara para el espacio que ésta ocupaba en la Mezquita Catedral malagueña ${ }^{7}$. Con motivo del traslado del culto a la nueva seo renacentista y del mobiliario en ella existente, se añadieron a este retablo los paisajes que conforman el sotobanco en la segunda mitad del siglo XVI para su instalación en la nueva capilla construida en la girola.

$$
\text { La hipótesis así planteada }
$$

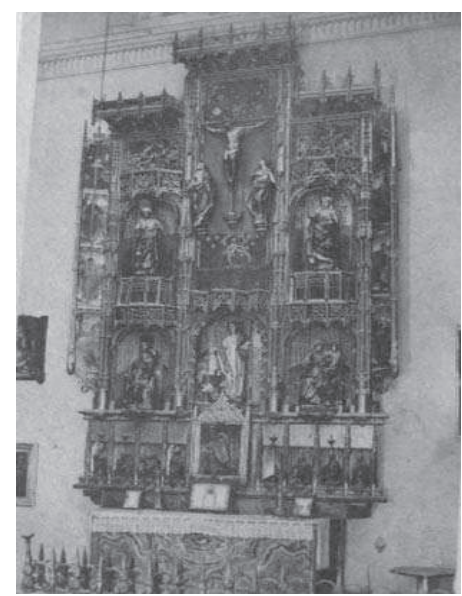

1. Retablo de Santa Bárbara de la Catedral de Málaga. $1920 \mathrm{ca}$.

resuelve el enigma de las diferencias de estilo y composición entre el resto del retablo, de estética gótica, y los paisajes, claramente más modernos. A ella se han ido sumando los investigadores que han tratado el tema del retablo malagueño de Santa Bárbara hasta el año 2000: Huertas Mamely8, Ordóñez Vergara $^{9}$, Romero Torres ${ }^{10}$ y Sauret Guerrero en sus trabajos del siglo $\mathrm{XX}^{11}$. Tan sólo encontramos una diferencia en sus planteamientos y es la fecha del traslado de dicho retablo: si para Pérez del Campo y Romero Torres ésta tuvo lugar en torno a 1588, coincidiendo con la consagración del nuevo edificio catedralicio, para Teresa Sauret la data es la de 159212, probablemente siguiendo la sugerencia de $\mathrm{M}^{\mathrm{a}}$ Dolores Aguilar ${ }^{13}$ sobre el cambio de ubicación de los res-

7 PÉREZ DEL CAMPO, L.: Op. Cit, pág. 78.

8 HUERTAS MAMELY, A.: Loc. Cit.

9 PÉREZ DEL CAMPO, L. y ORDÓÑEZ VERGARA, J.: Patrimonio y Monumento, Málaga, Universidad de Málaga, 1994, pág. 14.

10 ROMERO TORRES, J. L.: "El retablo de Santa Bárbara. (Santa Ana, Virgen y Jesús Niño)" en SÁNCHEZLAFUENTE GÉMAR, R.: El esplendor de la memoria. El Arte de la Iglesia de Málaga, Málaga, Junta de Andalucía, 1998, págs. 110-111.

11 SAURET GUERRERO, T.: Loc. Cit.

12 SAURET GUERRERO, T.: "La Catedral de Málaga: historia y características de su colección de bienes muebles" en RAMALLO ASENSIO, G. (coord.): El comportamiento de las Catedrales españolas. Del Barroco a los Historicismos. Actas del Congreso, Murcia, Universidad, 2003, pág. 347 


\section{Q: artículos Susana E. Rodríguez de Tembleque García}
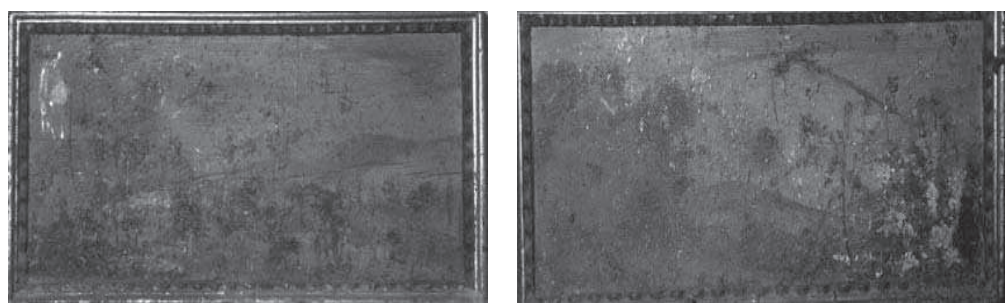

2y 3. Tablas del sotabanco antes de la restauración.

tos del canónigo del Pozo. Aunque ésta última afirma que se basa en una fecha de la lápida sepulcral, la única que aparece en la misma es la del óbito del fundador, 1531. Es más probable que dicha datación la tomen de Bolea y Sintas quien unifica el traslado en 1592 de los restos de los beneficiados desde la Catedral vieja con los de Francisco del Pozo ${ }^{14}$.

Una nueva perspectiva se abrió para este misterioso conjunto de paisajes a partir de la restauración del retablo dentro del programa bianual (19951996) del Departamento de Bienes Muebles del Servicio de Conservación y Restauración de la Dirección General de Bienes Culturales de la Junta de Andalucía. Por un lado, el retablo recuperaba su esplendor y, con él, el sotobanco que contiene los paisajes: "...se eliminó el humo de las velas depositado, los goterones de cera y barnices oxidados que se habían adherido a la superficie, formando una capa irregular"15.

Por otro lado, el equipo de la empresa restauradora Ágora, dirigido por Bárbara Hasbach Lugo, planteaba en 1996 una nueva de datación. Ésta queda involucrada en una serie de hipótesis sobre el conjunto de Santa Bárbara: "...el retablo se realizaría en dos momentos diferentes y con un lapso de tiempo casi de cuarenta años. En la primera etapa constructiva, a la que corresponderían los contratos de 1524 estudiados por Pérez del Campo, se realizaría la estructura del retablo, las esculturas y su policromía. Tras ésta, la obra sería paralizada, continuándose hacia la década de los sesenta, al asentarse el retablo en la capilla del nuevo edificio renacentista, realizándose en este momento el conjun-

13 AGUILAR GARCíA, Ma ${ }^{a}$ D.: "La Mezquita Mayor de Málaga y la iglesia vieja", en Boletín de Arte, n 6-7, 1985-1986, pág. 62.

14 BOLEA Y SINTAS, M.: Descripción histórica que de la Catedral de Málaga hace su canónigo doctoral Málaga, Universidad, 1998, pág. 249.

15 HERNÁNDEZ NÚÑEZ, J.C. y HASBACH LUGO, B.: "La restauración del retablo de Santa Bárbara de la 


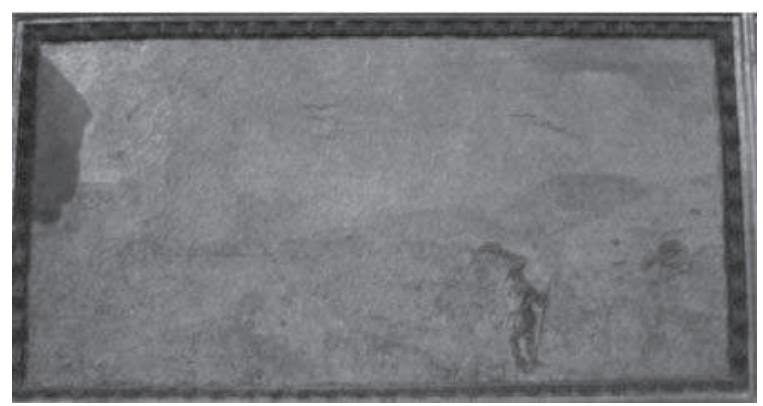

4. Est iter in siluis (Eneida VI, 271).

to de pinturas que adornan el guardapolvos"16. Las razones que aducen los promotores de esta segunda hipótesis se basan fundamentalmente en la simultaneidad en el tiempo entre el contrato de Nicolás Tiller y la aprobación por el Cabildo de la planta del nuevo edifico catedralicio, por lo que el retablo habría sido encargado teniendo ya en cuenta su ubicación definitiva en la capilla nueva de la girola y no en la Mezquita. Así no se habría hecho necesaria la adaptación del mismo con la incorporación del sotobanco, tan sólo se añadieron las ménsulas que hoy se aprecian en la parte baja del mismo, en 1562. Es alrededor de esta fecha cuando, según los autores de esta segunda hipótesis, fue colocado el retablo en la nueva Catedral.

Con estas conclusiones seguirían siendo una incógnita los paisajes y su datación. La solución que aportan estos investigadores es la siguiente: "Posteriormente, en la segunda mitad del siglo XVIII, se reformaría el retablo, con la sustitución de la imagen titular, del frontal del altar y con la colocación en el sotobanco de las pinturas paisajísticas"17. Las fechas exactas que barajan son las de 1768, coincidiendo con la sustitución de la imagen titular por otra de Fernando Ortiz, o la de 1780, cuando Juan de Altamirano costeó la renovación de los frontales de altar y la solería de la capilla.

A estas hipótesis se han sumado los siguientes autores: Hernández Núñez, Hasbach Lugo, Sauret Guerrero, en sus trabajos del siglo XXI18 y el

Catedral de Málaga", en Laboratorio de Arte, n 10, 1997, pág. 94.

16 HERNÁNDEZ NÚÑEZ, J.C. y HASBACH LUGO, B.: Op. Cit., págs. 85-86.

17 Ibídem.

18 SAURET GUeRRERO, T.: La Catedral de Málaga, Málaga, CEDMA, 2003, págs. 215-220. 


\section{Q: artículos Susana E. Rodriguez de Tembleque García}
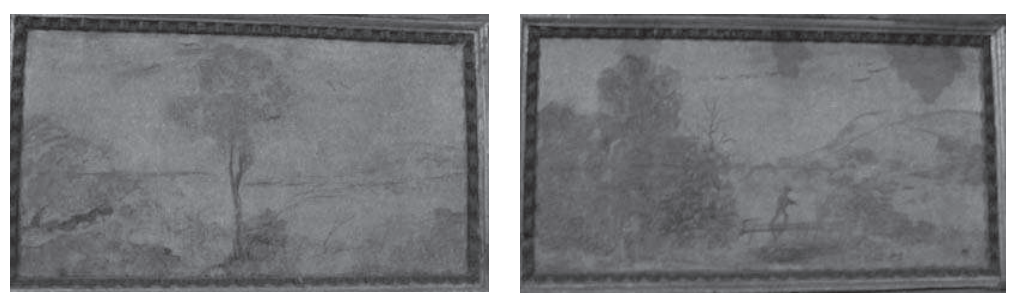

5. "In medio ramos annosaque brachia pandit / ulmus opaca, ingens". (Eneida VI, 282-283).

6. “Super quod lignum pontis... (Visión de Baronto). Erat autem ille presbiter peregrinus." (Visión de Tundale).

equipo que coordina Rosario Camacho en la revisada edición de la Guía histórico artística de Málaga ${ }^{19}$.

\section{EL CONTENIDO DE LOS PAISAJES.}

Son pocos los autores que se han fijado en el contenido de los paisajes y en sus características técnicas para hacer alguna aportación al tema de la datación y autoría. Hasta su restauración, era prácticamente imposible realizar una descripción de los mismos dadas sus condiciones de conservación.

Del proceso de restauración se desprenden sin embargo noticias clarificadoras aunque no con toda la profundidad posible: se trata de seis paisajes realizados al óleo sobre una sola tabla a la cual se han aplicado luego los marcos que dividen las escenas ${ }^{20}$. En el informe de restauración no aparece mención alguna sobre el análisis de pigmentos, que sí se hizo en la policromía de las imágenes y en las tablas de los guardapolvos 21.

Estos pequeños paisajes de formato apaisado han sido descritos por Huertas Mamely: "Representan una naturaleza agreste cuya expresividad y fuerza nos llega a través de la luz cálida con la que han sido concebidas, elemento que unifica toda la composición y que solamente pierde su protagonismo con la incorporación de elementos naturales con otras tonalidades, que indica los distintos planos de la trama. Todo ello tratado con una fuerza muy suelta que

19 "Son muy interesantes las delicadas pinturas de paisaje del sotobanco del retablo, obras del siglo XVIII". CAMACHO MARTÍNEZ, R. (coord.): Guía histórico artística de Málaga, Málaga, Arguval, 2006, pág. 122.

20 SAURET GUERRERO, T.: La Catedral..., pág. 220.

21 A.C.M. HASBACH LUGO, B.: Loc. Cit. 


\section{artícul os Elegía pintada. Los paisajes del retablo de Santa Bárbara...}

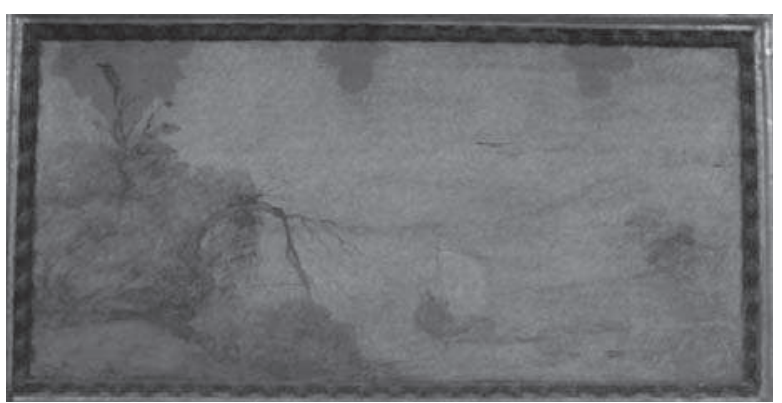

7. "Portitor has horrendus aguas et flumina seruat / terribili squalore Charon [...] ipse ratem conto subigit uelisque ministrat". (Eneida VI, 298299, 302)

envuelve la imagen en una aureola de lirismo y misterio"22. Estos tonos cálidos, en sepia con toques verdes, y la representación de unas aves en vuelo en todos los paisajes constituyen los elementos unificadores de los mismos, que adquieren gracias a ellos una continuidad expositiva ${ }^{23}$.

Esta continuidad no se ha visto alterada en su orden dada su realización sobre una única tabla. Ello permite una lectura lineal de los paisajes en los que una figura humana aparece en el primero, tercero y cuarto de los mismos caminando, cruzando un puente y viajando en un barco de vela. En los restantes, destacan un esbelto árbol en el segundo y sexto paisajes y un bosque en el quinto. Todos ellos mantienen la homogeneidad por la presencia constante de las mencionadas aves, el tono uniforme del cielo en colores cálidos y la reaparición de la misma figura masculina en aquellas escenas en las que hay una representación humana. Dada esta repetición del personaje se colige una lectura narrativa del conjunto en la que el protagonista, ataviado como un viajero con sombrero y cayado, emprende un camino hacia el Oeste en el que se suceden los avatares.

La descripción del sotobanco y el análisis de sus elementos nos llevan a un contenido de tipo escatológico: son la representación de los paisajes mitológicos del más allá, ambientados en el reino de Hades y en los Campos Elíseos y llenos de referencias literarias sobre la muerte y la salvación de los justos:

\section{HUERTAS MAMELY, A: Loc. Cit.}

23 PALOMO CRUZ, A.: La capilla de Santa Bárbara de la Catedral de Málaga, (en preparación). 
camino, mar, río, barco, bosques...24

La luz de tonos dorados nos habla de un paisaje crepuscular, situado al Oeste, hacia el fin del mundo, en la zona de Cádiz. Allí se localizan las Helíades y el Jardín de las Hespérides pero también el reino del Hades, al que se llega después de la Muerte. Y precisamente la representación de los paisajes arranca con una lectura, según la ubicación del retablo que lo alberga en la capilla de Santa Bárbara, de Este a Oeste, de izquierda a derecha, del Hades a los Campos Elíseos y a las Islas de los Bienaventurados: "Allí no hay noche, ni día del todo claro. Un crepúsculo parecido al de la aurora, predecesora del sol, alumbra aquella tierra...", como la describe Luciano.

De las fuentes clásicas surgen dos vías para llegar al más allá: atravesando el océano, es decir la muerte, en barco, como Ulises, y a pie, como Eneas, que desciende al Hades a través de una gruta o sima. Esta idea del viaje al otro mundo a pie aparece reforzada por la costumbre griega clásica de depositar zapatos en las tumbas 25 . Es éste el modelo que sigue el personaje de los paisajes: el peregrino ultramundano, homo viator de la literatura ${ }^{26}$, que vive la muerte como una nueva etapa de su peregrinatio vitae. Aparece en el primer momento como un caminante solitario y perdido ante un paisaje que se nos antoja una representación más del locus amoenus pero en este caso con alusiones escatológicas: “...errante me encontré por selva oscura, / en que la recta vía era perdida"27. Aparecen todos los elementos del lugar ameno: un prado, un árbol o varios, una fuente, un río y unos pájaros ${ }^{28}$ pero con referencias a la otra vida, donde no reina la primavera sino el otoño, al menos en las cuatro primeras representaciones.

La presencia de las aves es una constante en las Nekia, el canto undécimo de la Odisea y el sexto de la Eneida. Son las almas ululantes de los difuntos que gritan: "En torno suyo había un estrépito de cadáveres, como de pájaros, que huían asustados en todas direcciones" 29 . En las representaciones grá-

24 ÁLVAREZ MARTÍNEZ, Ma.: Conformaciones literarias del tema de la muerte en la lírica española. Madrid, Universidad Complutense, 1990, págs. 120-121.

25 VELASCO LÓPEZ, M M H.: El paisaje del más allá. El tema del prado verde en la escatología indoeuropea. Valladolid, Universidad, 2001, pág. 106.

26 "Pasos de un peregrino son, errante, / cuantos me dictó versos dulce Musa / en soledad confusa, / perdidos unos, otros inspirados". GÓNGORA, L.: Dedicatoria de Las Soledades.

27 DANTE: Divina Comedia, Infierno I.

28 OROZCO DÍAZ, Emilio: Paisaje y sentimiento de la Naturaleza en la poesía española. Madrid, Centro, 1974, pág. 33.

29 Odisea, canto XI. Para los romanos son otras aves, águilas psicopompas, las que transportan las almas al otro mundo. De igual modo, hay una alusión al mito de Memnón, difunto hijo de la Aurora que llora cada mañana por él, mientras que unas aves maravillosas surgidas de sus cenizas, acuden cada año al lugar de la muerte de su padre y se sacrifican por él, según Ovidio en sus Metamorfosis. 

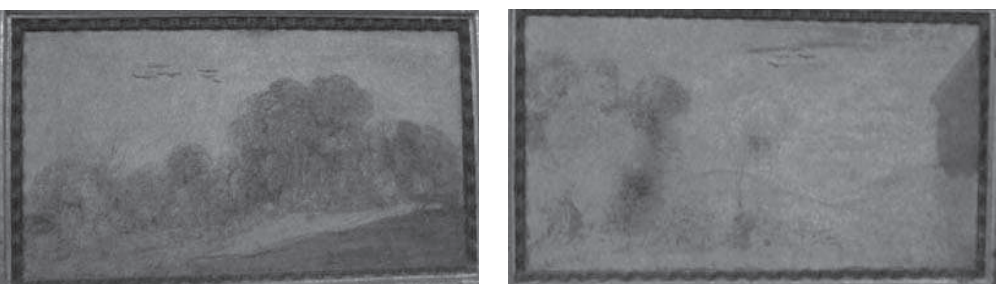

8. "Deuenere locos laetos et amoena uirecta / fortunatorum nemorum sedesque beatas. (Eneida VI, 638-639)

9. Un árbol había en el centro de la tierra, de altura muy grande. (Daniel 4, 7).

ficas de la antigüedad clásica aparecen como eidola, insectos o aves levemente humanas ${ }^{30}$, y en la literatura medieval del más allá son "almas en forma de pájaros negros que padecen en el fuego y suplican y aúllan y gritan con voces humanas" 31 . La literatura castellana las recogió en las obras de Soto de Rojas: "Que turba escuadra de nocturnos vuelos"32; y Luis de Góngora: "Infame turba de nocturnas aves, / gimiendo tristes y volando graves"33.

Lo primero que Ulises encuentra en su viaje ultramundano es el bosque de Perséfone, el cual Polígnoto de Thasos en su Nekya, había reducido a un solo árbol. Para Eneas, sin embargo, el árbol que encuentra en su camino es el olmo del que penden los falsos sueños: "En el centro despliega sus añosas ramas un inmenso olmo, y es fama que allí los vanos sueños, adheridos a cada una de sus hojas"34. Ambas lecturas se encuentran en la segunda escena del sotobanco del retablo en el que no aparece la figura del peregrino.

En el más allá de la mitología grecolatina, el juicio de las almas tenía lugar ante los jueces del inframundo Minos, Eaco y Radamanto quienes enviaban las almas al Erebo, los prados de gamones o asfódelos donde vagaban errantes durante un tiempo, o al Tártaro, donde eran castigados por las Furias, o al Elíseo, como recompensa. Este elemento pagano de juicio fue sustituido en la literatura medieval escatológica por el puente angosto que se ensancha a

30 DÍEZ DE VELASCO ABELLÁN, F.: "La iconografía de Caronte: un análisis puntual del LIMC", en Gerión, $n^{\circ} 7$, Madrid, Universidad Complutense, 1989, pág. 316.

31 Visión de Baronto, apud PATCH, H. R.: El otro mundo en la literatura medieval. Madrid, Fondo de Cultura 31 Visión de Baronto, apud PAT
Económica, 1983, pág. 110.

32 "Paraíso cerrado para muchos, jardines abiertos para unos pocos", 14.

33 Fábula de Polifemo y Galatea, 5.

34 Eneida, canto VI, vv. 282-284. 


Q artículos Susana E. Rodríguez de Tembleque García

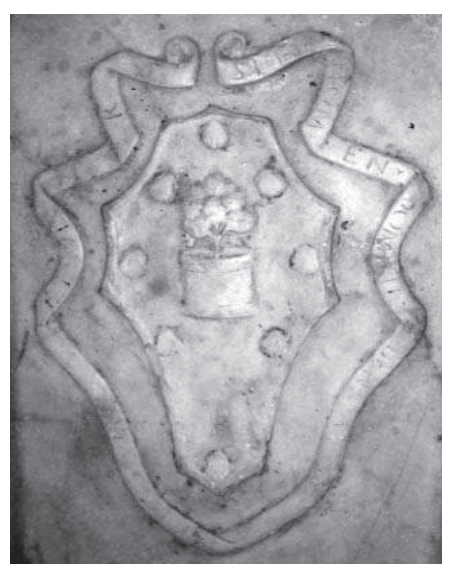

10. FRANCISCO DEL POZO, detalle de la lápida sepulcral.

medida que avanza el justo y se estrecha al paso del malvado. La referencia más antigua al mismo es del siglo VI y se encuentra en la obra de Gregorio I Dialogui de uita et miraculis patrum Italicorum y reaparece en las versiones tardías del Apocalipsis de Esdras: "et pons iste reuertebatur in subtilitatem ut filium staminis et cadebant in hoc flumen confitenetes pecata sua"35. De ahí pasó a los Apocalipsis medievales y a la literatura oriental, convirtiéndose en un lugar común en las visiones del otro mundo desde el siglo $\mathrm{X}$ hasta quedar consagrado en la obra de Dante, repleta de puentes ${ }^{36}$. La ya citada Visión de Baronto del siglo VII y la Visión de Tundale del XII, describen como elemento de juicio un puente de madera con unos detalles destacables: "Nadie podía cruzarlo sino los elegidos. Muchos trataban de pasarlo; pero sólo pudo hacerlo un sacerdote que llevaba la palma de su peregrinación"37.

En el viaje que emprende el peregrino de los paisajes del retablo de Santa Bárbara se está hablando de un hombre justo, un sacerdote, que ha muerto y ha alcanzado la salvación, pues el puente angosto, de la tercera escena, le ha permitido pasar. A la izquierda del puente, sobre una elevación parece descubrirse una fuente, tal vez Mnemósime, la de la Memoria, y un árbol sin hojas que recuerdan en qué parte del Averno se encuentra el protagonista. Las

35 PATCH, H. R.: Op. Cit., pág. 97.

36 COULIANO, I. P.: Más allá de este mundo. Paraísos, purgatorios e infiernos: un viaje a través de las culturas religiosas, Barcelona, Paidos, 1993, págs. 217-218.

37 PATCH, H. R.: Op. Cit., pág. 121. 


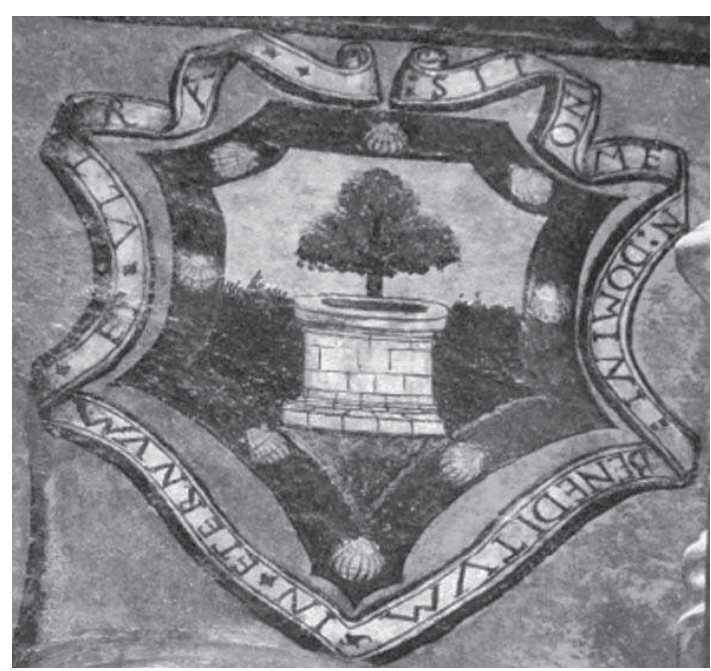

11. Escudo de los guardapolvos del retablo de Santa Bárbara.

representaciones de Perséfone se identifican con álamos negros y granados y sauces sin hojas. Precisamente, un salguero estéril de este tipo aparece en el siguiente paisaje.

La última aparición del viajero de Santa Bárbara corresponde al cuarto paisaje. En él, el protagonista viaja en un barco de vela que guía otro personaje. A la izquierda, al Este, queda el Erebo, con sus marjales y sus árboles desnudos. A la derecha, al Oeste, hacia el fin del mundo, se extiende una masa de agua, el Ponto que separa como una frontera el Hades de las Islas de los Bienaventurados ${ }^{38}$. Según las descripciones clásicas las almas de los difuntos deben cruzar el Aqueronte, el río de la pena, y los brazos de la laguna Estigia donde iban a parar los restantes ríos del Averno: el Cócito, el Flegetonte y el Leteo, el río del olvido que se corresponde con el Guadalete ${ }^{39}$. Para llegar a su

38 DIEZ DE VELASCO, F.: "El agua en el viaje de la muerte en la Grecia antigua: identidad y memoria" en MARTÍNEZ, M.: La cultura del viaje, $2^{a}$ semana canaria sobre el mundo antiguo, Madrid, Ediciones Clásicas, Universidad de La Laguna, 1999.

39 Referencia aún viva en la literatura española: "Cruzó el río y cuando volvió no recordaba nada. [...] El río se llama Guadalete. Es una palabra árabe que viene del griego. Los antiguos le llamaban Leteo, el río del olvido, porque era la frontera entre el reino de los vivos y el de los muertos. Quien lo cruza pierde la memoria". MUÑOZ MOLINA, A.: Nada del otro mundo, Madrid, Espasa-Calpe, 1994, págs. 89-90. 


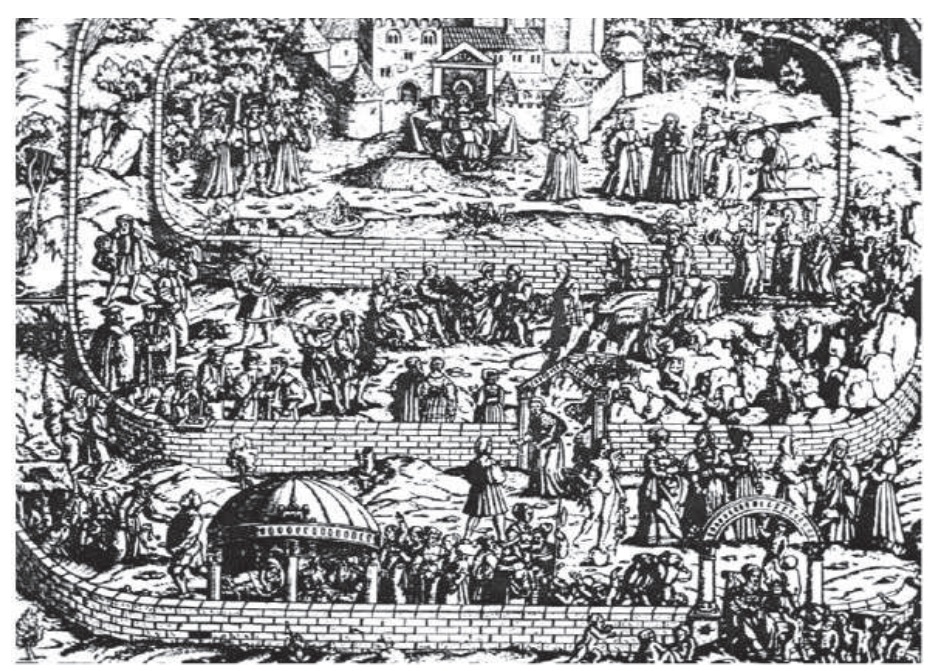

12. D. KANDEL, La tabla de Cebes, 1547.

destino final, el viajero necesita la ayuda de un psicopompo: en este caso Caronte. Ni Hermes, ni Hypnos ni Thanatos ni san Miguel son válidos puesto que, salvo por el elemento del juicio, el viajero sigue la ruta clásica de Eneas que recurre al más popular y optimista de de ellos ${ }^{40}$. Si bien tanto en los lécitos griegos como en la representación consagrada por Miguel Ángel en la Capilla Sixtina, se trata de un barquero, el autor de los paisajes tiene un manejo de las fuentes de primera mano, pues el Caronte de la Eneida apareja las velas de su nave, tal y como se recoge en esta representación.

La pervivencia del barco como final del viaje y del mito de Caronte en la literatura española hasta fechas muy cercanas, aparece fielmente recogido en la obra de Antonio Machado: "Y cuando llegue el día del último viaje, / y esté al partir la nave que nunca ha de tornar, / me encontraréis a bordo ligero de equipaje, / casi desnudo como los hijos de la mar"41. O, igualmente, en el soneto dedica-

40 DÍEZ DE VELASCO ABELLÁN, F.: Los caminos de la muerte: religión, rito e iconografía del paso al más allá en la Grecia antigua, Madrid, Trotta, 1995.

41 MACHADO, A.: Poesías completas, Madrid, Espasa Calpe, 1966, pág. 77. 
artículos Elegía pintada. Los paisajes del retablo de Santa Bárbara...

do a Valle-Inclán: "Yo era en mis sueños, don Ramón, viajero / del áspero camino, y tú, Caronte / de ojos de llama, el fúnebre barquero / de las revueltas aguas del Aqueronte. [...] Porque faltó mi voz en tu homenaje, / permite que en la pálida ribera / te pague en áureo verso mi barcaje" 42 .

La aparición del barco funerario, ya desde la epopeya de Gilgamesh y el antiguo Egipto hasta la época clásica, es un referente constante en las tumbas, como alusión escatológica al paso del alma del difunto a las Islas de los Afortunados. De los sarcófagos romanos, fue copiado por los artistas italianos e incluido en los programas iconográficos de los sepulcros. Aunque el cristianismo lo había seguido empleando como signo de salvación en el viaje de la vida que llega al puerto del Paraíso, fue recuperado por los humanistas entre otros símbolos que, sólo comprendidos por una minoría de iniciados, hacían votos de inmortalidad y de salvación por difunto ${ }^{43}$. El mismo Alciato, asocia el barco a la Esperanza en su emblema XLIII: "Spes proxima" y Polifilo viaja en una nave semejante a la isla misericordiosa que era el retiro de los Bienaventurados, en la obra de Francesco Colonna44. En el presente paisaje el barco adquiere así todo el significado del premio al alcance, el fin del viaje, reflejado en las dos representaciones que le siguen.

Desde el siglo IV, para los cristianos letrados, el Paraíso se identifica con la imagen del paisaje de los Campos Elíseos, compartiendo sus elementos ${ }^{45}$. Por eso, para indicar que el viajero de los paisajes, hombre justo que ha superado el juicio y ha embarcado hacia su destino de salvación, llega al cielo, se representan los bosques de laureles reservados a los héroes que han muerto por su patria, a los sacerdotes virtuosos y a los poetas y artistas de memoria inmortal, como los canta Virgilio.

En la descripción del Elíseo atribuida a Tertuliano se resumen sus características, muchas de ellas tomadas de Hesíodo: la luz es clara, el aire salubre, los campos son fértiles, las flores ricas, el aire fragante, los árboles están colmados de fruta, "nulla cadunt folia", hay un lago y una fuente que se divide en cuatro partes, reina eterna primavera, no hace frío, ni calor, ni se conoce la noche, todos los males están ausentes ${ }^{46}$. Estos son los elementos que aparecen reflejados en los dos últimos paisajes.

\footnotetext{
42 Ibídem, pág. 216.

43 REDONDO CANTERA, M. J.: El sepulcro en España en el siglo XVI: Tipología e Iconografía, Madrid, Ministerio de Cultura, 1987, págs. 145 y 222.

44 BLÁZQUEZ MATEOS, E.: Viajes al Paraíso: la representación de la naturaleza en el Renacimiento, Salamanca, Universidad de Salamanca, 2004, pág. 97.

45 VELASCO LÓPEZ, M. H.: Op. Cit., pág. 167.

46 PATCH, H. R.: Op. Cit., pág. 145.
} 
En el quinto paisaje, unos bosques verdes marcan el contraste con los anteriores. Ya no aparecen árboles sin hojas, sino que todos son frondosos y tupidos, de amena umbría. En el último, junto a una masa boscosa aparece separado un gran árbol de prolongada sombra que recuerda el del segundo paisaje. En las representaciones medievales del Paraíso se relaciona con el árbol central del Edén del libro del Génesis del que surgen cuatro ríos. Pero en las visiones escatológicas como la ya mencionada Visión de Tundale, el final del viaje está presidido por un árbol enorme cubierto de frutas, flores y pájaros a cuya sombra descansan los bienaventurados, "se dice que el árbol es la Santa Iglesia"47. La representación es un reflejo de la visión de Nabucodonosor en el libro de Danie/48 que fue interpretada desde el siglo IV como una imagen de Jesucristo: “...así como por el árbol se entiende Christo, y por las frutas sus buenas obras, así por las hojas se entienden sus gloriosas palabras", su sombra es la gracia divina, "los nidos que allí están son nuestros corazones; [...] ningún árbol del Paraíso se puede comparar con Christo"49.

Asistimos en el contenido de estos seis paisajes al elogio y anuncio de salvación de un personaje representado como un peregrino del más allá que alcanza la vida eterna y el premio de los héroes y los justos. Esto se hace mediante elementos de difícil comprensión, por lo que la erudición del autor de los paisajes o del mecenas que encarga la obra queda patente frente al programa del resto del retablo de clara lectura en un contexto de iconografía cristiana. Todos estos elementos se encuentran reunidos en la tradición literaria que recoge, en la transición del siglo XV al XVI, la obra de Diego Guillén de Ávila50.

A la manera de las antiguas tumbas de los héroes, esta alabanza del difunto personaje, está adornada de praderas, bosques y plantas. Así lo estaba el mausoleo de Augusto, según lo describe Estrabón: se trataba de un túmulo cubierto de árboles de hoja perenne y rodeado de un jardín. Así también aparecían en las pinturas funerarias de héroes de Polígnoto, según las describe Pausanias ${ }^{51}$.

El hecho de que se trate de una alabanza, que sólo unos pocos versados

\footnotetext{
47 Ibídem, pág. 122.

48 "Un árbol había en el centro de la tierra, de altura muy grande. El árbol creció, se hizo corpulento, su altura llegaba hasta el cielo, su expansión, hasta los confines de la tierra. Era hermoso su ramaje, abundante su fruto; había en él comida para todos, a su sombra se cobijaban las bestias del campo, en sus ramas anidafruto; había en él comida para todos, a su sombra se cobijaban las bestias
ban los pájaros del cielo, y toda carne se alimentaba de él". Daniel 4, 7-9.

49 GUEVARA, A.: Todos los misterios del Monte Calvario, Madrid, Isidoro Hernández Pacheco, 1782, págs. 208-219.

50 LIDA DE MALKIEL, M. R.: "La visión de trasmundo en las literaturas hispánicas" apéndice de PATCH, H. R.: Op. Cit., pág. 396.

51 VELASCO LÓPEZ, M. H.: Op. Cit., pág. 89.
} 
en los textos de la Antigüedad clásica pueden conocer, enlaza de nuevo una de las características del Humanismo que se destaca por su difícil comprensión de los símbolos ${ }^{52}$ y por la utilización del tema escatológico de las Hespérides en elogio de un mecenas ${ }^{53}$. Un ejemplo español en el que los paisajes del Hades se representen en una obra funeraria renacentista con las mismas características otoñales que los de la de Santa Bárbara, se encuentra en la Catedral de Sigüenza, en los frescos de Francisco Pelegrina para la capilla de la Concepción 54 .

Y es de nuevo la descripción de la propia tabla la que invita a una lectura aún más relacionada con la Literatura. Si el fondo de los paisajes es un canto fúnebre, la forma refuerza este mismo sentido poético. El sotobanco del retablo de Santa Bárbara, no es una continuación de éste, a modo de añadido integrado, ni sigue el número de sus calles ni el de los nichos de la predela. Es, dentro de él, un elemento independiente en el que el número seis es relevante, pues seis son los pies del hexámetro dactílico, primer verso del dístico elegíaco, es decir, de la expresión clásica de la poesía elegíaca en latín que se siguió empleando hasta el Renacimiento. El ejemplo más representativo es la obra de Giovanni Pontano, considerado la cumbre de la poesía neolatina del Renacimiento y autor de De tumulis. Esta obra escrita en hexámetros dactílicos es una colección de epitafios dedicados a distintas personas a las que ensalza y garantiza la salvación enviándolos a un cielo que identifica con los Campos Elíseos del mundo subterráneo pagano. Allí sus amigos y conocidos gozan de la esperanza reservada a los héroes, después de su muerte que para Pontano es el paso a la otra vida55. Este género denominado tumulus, en dísticos elegíacos, fue cultivado por numerosos autores neolatinos, entre ellos el español Calvete de Estrella en su obra Tumulorum Liber Vnus, como poemas fúnebres ${ }^{56}$.

La posibilidad de que los paisajes tengan este matiz elegíaco, se confirma en la ya mencionada constante presencia de las aves. Éstas hacen referencia también a la etimología de la voz "elegía": "Para Aristóteles eleos es el nombre de un ave nocturna, la que los latinos conocían por ulula y los italianos por

52 REDONDO CANTERA, M. J.: Op. Cit., pág. 145.

53 BLÁZQUEZ MATEOS, E. "El mito de las Hespérides y las alegorías mitológicas en el Humanismo hispano. El ciclo pictórico-literario para el jardín pintado del Marqués de Santa Cruz", en Boletín del Museo del Instituto Camón Aznar, n 73, 1998, pág. 9.

54 BLÁZQUEZ MATEOS, E.: Viajes al Paraíso..., pág. 93.

55 PARRA GARCÍA, L.: "La poesía latina del Renacimiento: ¿Cristianización de lo pagano o paganización de lo cristiano? El caso de G. C. Pontano", www.anmal.uma.es/numero6/Parra.htm, [Fecha de la consulta: 28-2-2007].

56 DÍAZ GITO, M. A.: "Poesía elegíaca de Calvete de Estrella: poema a la muerte de un pajarito" en MAESTRE MAESTRE, J. Ma (coord.): Humanismo y pervivencia del Mundo Clásico. Alcañiz, Instituto de Estudios 
aluco"57. Este valor etimológico fue recogido por los autores humanistas, como Fernando de Herrera, quienes consideran la elegía un canto de muerte 58 .

Por su carácter elegíaco, los paisajes hacen alusión directa a un personaje difunto y a su enterramiento. El único sepulcro relevante que existe en la capilla de Santa Bárbara y que puede estar en relación con los paisajes del retablo es el del canónigo Francisco del Pozo del siglo XVI.

3. Francisco del Pozo y Juan de Valencia.

No son muchos los datos que se conocen de estos destacados personajes, aunque dado su protagonismo, debieron figurar entre los presbíteros más relevantes en la Málaga del siglo XVI.

Nació Francisco del Pozo en Cuenca y llegó a Málaga en 1500 de la mano del obispo Ramírez de Villaescusa quien le fue otorgando sucesivas dignidades en su diócesis: racionero de la Colegiata de San Sebastián antequerana, mayordomo de la casa del Obispo y canónigo de la Catedral malagueña. A ello se une su interés en ser recordado por la posteridad a través del patronato de la capilla de Santa Bárbara. Memoria que se mantuvo, mientras sus parientes fueron capellanes de la misma, denominándola por el apellido "del Pozo" si bien Medina Conde, no pudiendo identificarla, supuso que era la de las Reliquias, hoy del Pilar, también colateral a la de la Encarnación y que tuvo un pozo de agua 59

La capilla de Santa Bárbara había sido fundada por una familia de artilleros oriunda de Écija, los Páez. La viuda del fundador, incapaz de mantener el patronato, lo devolvió al Cabildo que, a su vez, lo adjudicó a Francisco del Pozo60. Es ésta la razón de su titularidad.

En 1513 erigió el nuevo patrono dos capellanías adscritas a su capilla. En 1524 contrató con Nicolás Tiller el retablo que aún hoy la preside. Renovó la erección de capellanías, manteniendo las condiciones y aumentando a cuatro su número, en 1530. Finalmente, poco antes de morir, en 1531, otorgó testamento ante el notario Antón López, disponiendo en el mismo su voluntad en cuanto a entierro y sepultura.

Humanísticos, 2002, t. III, pág. 1006.

57 CORREA RODRÍGUEZ, P.: "Fernando de Herrera: poesía 'elegidia' clásica y elegía renacentista", Ágora. Estudos Clássicos em Debate, n² 2, 2000, pág. 190.

58 Ibídem, pág. 191.

59 MEDINA CONDE, C.: La Catedral de Málaga, Málaga, Arguval, 1984, pág. 48.

60 GONZÁLEZ SÁNCHEZ, V.: "De Mezquita mayor de Málaga a Catedral renacentista. Descubrimiento de un elemento revelador de una metamorfosis, pasando por la iglesia vieja", Isla de Arriarán, n 7,1996 , págs. 
Además de las obligaciones que debían cumplir sus capellanes en lo referente a misas, fiestas, oficio coral etcétera, el canónigo del Pozo estableció tres lugares de enterramiento en su capilla de la Catedral Mezquita: el primero de ellos se encontraba delante de la misma "que está solada de ladrillo nuevo para enterramiento de los dichos capellanes" 61 . El segundo estaba destinado a su sobrino Pedro del Pozo, su mujer, sus hijos y cuantos familiares del canónigo murieran en Málaga. Y el tercero, para el propio Francisco del Pozo y su hermano, canónigo de la Catedral de Cuenca: "...que en mi sepultura no se entierre otro cuerpo si[no] el mío o el de mi Señor hermano Juan del Poço si fuere la voluntad de Dios que falleciere aqui"62. Es éste el que fue trasladado a la capiIla de Santa Bárbara de la Catedral nueva, en la segunda mitad del siglo XVI.

El sepulcro de Francisco del Pozo, de concepción horizontal, se reduce a una lápida rectangular en la que la representación del difunto ha sido sustituida por su escudo y divisa. En derredor de la lápida, una faja bordea su perímetro conteniendo el epitafio: "Aquí yaze sepultado el Revendo Señor Francisco del Pozo Canónigo de esta Sancta Yglesia de Málaga, Beneficiado de la Cibdad de Antequera. El qual edificó i dotó esta capilla de Señora Santa Bárbara, falleció el año de 1531 a 4 de agosto".

Es el contenido del escudo, el que interesa destacar. Aparece en él el brocal de un pozo del que sale un árbol. Está rodeado por ocho veneras o peregrinas. Su divisa, sobre una cinta alrededor, aún es legible: "INE TER[T]IVM ET VLTRA. SIT NOMEN DOMINI BEN [EDICT]VM"63. A pesar de sus dignidades eclesiásticas, no incluyó el canónigo del Pozo en su escudo un capelo con borlas como le correspondía 64

Estos elementos del escudo parecen estar en relación directa con el contenido de los paisajes. No sólo por el árbol que surge del pozo y parece el mismo del segundo paisaje en cuanto a especie, tamaño y disposición de su copa, sino que las conchas que lo orlan eran signos seculares de peregrinos, como el personaje del viaje de los paisajes. Éstos, habiendo alcanzado la meta

110-111.

61 Escritura de fundación de cuatro capellanías erigidas en 1530 en la capilla de Santa Bárbara por el canónigo D. Francisco del Pozo. A. C. M. Legajo 19, pieza 15. Este lugar fue designado en 1574 por el obispo Francisco Blanco Salcedo para enterramiento de los beneficiados de la Catedral. BOLEA Y SINTAS, M: Op. Cit., pág. 180.

62 Copia del testamento del Canónigo Francisco del Pozo en 1531 ante Antón López. A. C. M. Leg. 19, pieza 16.

63 Es éste el texto que se ve en la lápida sepulcral. Sin embargo, en los guardapolvos del retablo aparece el mismo escudo con tres variantes: en el propio escudo, el pozo se rodea de un paisaje vegetal en verde intenso y el árbol no surge del mismo sino que aparece tras el brocal; la última, en la divisa en la que en un latín no tan purista se lee: "Sit nomen Domini benedictum in eternum [sic] et ultra".

64 REDONDO CANTERA, M. J.: Op. Cit., pág. 307. 
de Santiago de Compostela, visitaban el Finis Terrae, el lugar más occidental del mundo, y recogían de sus playas estos recuerdos que ostentaban durante su regreso como prueba de haber alcanzado su meta y de haber visitado los confines de la tierra. La clave, sin embargo, está en el pozo que siempre ha tenido un sentido escatológico de paso y comunicación con el infierno y el mundo subterráneo65. Son muchas las simas que aún hoy reciben la denominación de "pozo del infierno" mientras que en la cultura hebrea el pozo realizaba la síntesis de los tres órdenes cósmicos: cielo, tierra e infierno.

De la divisa, la primera parte es a su vez significativa, admitiendo además varias interpretaciones. "Entra por tercera vez y más allá", parece hacer referencia a la vida del difunto. La primera vez sería la entrada a la vida cristiana a través del Bautismo, la segunda a la vida sacerdotal y la tercera a la vida eterna. El "más allá" sería así el cielo.

Pero para una persona cultivada del siglo XVI existe en el texto una connotación con la famosa Tabla de Cebes o Pínax. Esta obra fue conocida desde el siglo I hasta el XVIII en ambientes docentes por todos aquellos que estudiaban griego o latín pues por su sencillez constituía, junto con las oraciones de Isócrates, uno de los primeros ejercicios de traducción que realizaban los jóvenes estudiantes. Como parte del acervo cultural de toda persona instruida se convirtió en un lugar común en el siglo XVI en representaciones literarias y artísticas. Así su huella se rastrea en multitud de obras, como el ya mencionado Viaje de Polifilo o en los Sueños de Quevedo. Dada su brevedad circuló manuscrita, en griego y en latín, entre los humanistas y fue impresa en diversas lenguas, alcanzando para 1550 más de sesenta ediciones 66 .

Es su contenido filosófico, perfectamente adaptable a la moral cristiana, el que a su vez nos da una clave de interpretación de la divisa del escudo de Francisco del Pozo. En forma de diálogo, describe los dibujos de un cuadro (pínax) en el que se representa la vida humana como un camino hacia la felicidad y en busca de la verdadera doctrina. El escenario de esta peregrinatio vitae son tres recintos concéntricos con sus respectivas puertas: el primero es la vida; el segundo, la Falsa Doctrina; y el tercero, la Verdadera. Más allá, ultra, se llega a un locus amoenus, lleno de árboles, prados, luz y serenidad donde moran los bienaventurados y donde están las Virtudes y la Prudencia. En el centro tiene su trono la Felicidad que corona como héroes a los que consiguen llegar hasta allí. Todo este itinerario se encuentra lleno de imágenes simbólicas alusivas a la loca y ciega Fortuna y sus dones, los castigos y los dolores, las Letras, las

65 PATCH, H. R.: Op. Cit., pág. 12

66 LÓPEZ POZA, S.: “La ‘Tabla de Cebes' y los 'Sueños' de Quevedo”, Edad de Oro, n 13, 1994, pág. 88. 


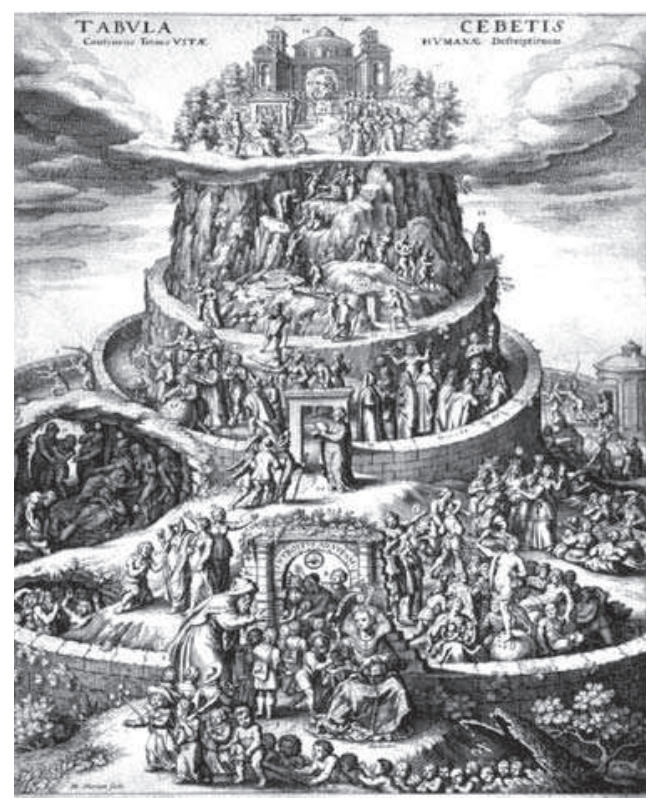

13. MATTHÄUS MERIAN, Tabula Cebetis, 1672.

Artes, el Engaño, la purificación, los vicios y las virtudes que el hombre encuentra a lo largo de su vida... todos y cada uno de ellos representados por figuras humanas con atributos alegóricos.

El Ine tertium et ultra de la divisa del escudo es reconocible por cualquiera que conozca este argumento de la Tabla de Cebes como una invitación a cruzar la tercera puerta, donde está la Verdadera Doctrina, y entrar así en la morada de los bienaventurados y avanzar más allá hasta ser coronado por la Felicidad. Este paraje es descrito en el texto de manera semejante a los dos últimos paisajes del sotobanco: “¿Ves, además -continuó- y en frente de aquel bosque, un lugar de tan agradable aspecto, a una manera de prado, bañado todo de una gran lumbre?"67.

La Tabla de Cebes es una de las muchas representaciones tradicionales del hombre como peregrino en la tierra. Entre las más destacadas están además: el laberinto, la $Y$ pitagórica, el cercado o montaña ascensional, Hércules

67 Manual de Epícteto seguido de la Tabla de Cebes, Barcelona, Montaner, 1943, pág. 163. 
en la encrucijada y los tableros de juego entre los que cabe destacar dos, por los elementos con que representan el itinerario del hombre por la vida, la Filosofía cortesana moralizada de Alonso de Barros, impresa en 1587, y el conocidísimo juego de la oca, encargado en 1580 por Francesco de Medici como regalo para Felipe II y que ha perdurado en el tiempo muy popularizado68. Ambos toman símbolos ya conocidos de los tableros de juego que les precedieron consagrándolos con todo su significado: el puente, el pozo, la barca y la muerte, todos ellos presentes en los paisajes del sotobanco de Santa Bárbara y en el escudo de la lápida funeraria de Francisco del Pozo de la misma capilla. Por lo que entre el sepulcro y los paisajes se establece una relación de complementariedad, manteniendo cada uno su unidad de interpretación y enriqueciendo sus significados para aquellos que conocen estas posibilidades.

No es de extrañar que esto suceda en una capilla de la Catedral vieja como es la de Santa Bárbara. Según parece, se convirtió, por sus dimensiones, situación y existencia de un coro propio para sus capellanes, en uno de los focos culturales de la Málaga renacentista. Allí tenían lugar las oposiciones de los prebendados de la seo malacitana69. Allí se interpretaban los autos sacramentales para las fiestas del Corpus Christi 70 . Y, lo que es más importante, allí tenían lugar los actos literarios y las representaciones de las comedias de tipo académico que el bachiller Juan de Valencia escribía para los alumnos del Estudio de Gramática de la Catedral ${ }^{71}$.

Este filólogo resulta fundamental para conocer la vida cultural del siglo XVI en esta provinciana ciudad: "No es posible ignorar su huella"72. Él junto con Juan de Vilches en Antequera y Luis de Linares en Ronda representan los focos del Humanismo en Málaga. Era Juan de Valencia natural de Loja, bachiller, racionero y catedrático de Gramática en el Estudio de la Catedral desde los años cuarenta. Su labor vino apoyada también por el obispo humanista Diego Ramírez de Villaescusa que había sido a su vez catedrático de Salamanca y hombre de letras muy respetado por Nebrija ${ }^{73}$. Fue Valencia más filólogo que

68 LÓPEZ POZA, S.: "Expresiones alegóricas del hombre como peregrino en la tierra" en AA.VV.: De oca a oca... polo Camiño de Santiago, Santiago de Compostela, Xunta de Galicia, 2004, págs. 64 y 67.

69 GONZÁLEZ SÁNCHEZ, V.: Loc. Cit.

70 BOLEA Y SINTAS, M.: Op. Cit., pág. 163. En tanto no sean restauradas para su conservación y consulta las Actas Capitulares de estas fechas, se hace necesario acudir a una fuente secundaria fiable como es ésta. 71 Ibídem, pág. 139. AGUILAR GARCÍA, M. D.: Loc. Cit.

72 TALAVERA ESTESO, F. J.: "Escritores humanistas en la Málaga del XVl" en WULFF ALONSO, F., CHENOLL ALFARO, R. y PÉREZ LÓPEZ, I. (eds.): La tradición clásica en Málaga (siglos XVI-XXI), Málaga, CEDMA, 2006, pág. 255.

73 TALAVERA ESTESO, F. J.: Juan de Valencia y sus Scholia in Andrea Alciati Emblemata, Málaga, Universidad, 2001, pág. 16. 
artículos Elegía pintada. Los paisajes del retablo de Santa Bárbara...

literato aunque, como destacan las noticias que de él se conservan, compuso numerosas obras teatrales, autos y poemas neolatinos en hexámetros como el de Pyrene. Fundamentalmente su labor docente ha dejado memoria de su actividad y entusiasmo en el conocimiento y la difusión de la cultura clásica y de la lengua latina.

Tenía el Estudio de Gramática su ubicación en la claustra de la Catedral Mezquita. Contó Valencia con un importante número de alumnos, llegando de ochenta a cien en los cursos 1547-1548. Por ello contaba con la ayuda de repetidores: Bernardo de Castro y Gregorio de Orduña ${ }^{74}$. Entre los alumnos más destacados de Juan de Valencia sobresalen Luis y Alfonso de Torres, Antonio Hojeda y Bernardo Alderete quien llegó a hablar del catedrático como "mi maestro, al que los hijos de Málaga deuen mucho"75.

De su obra se conservan los Escolios a los Emblemas de Alciato. En ellos no sólo destaca su interés por el tema del simbolismo, sino que demuestra su erudición y conocimiento del mundo clásico a través de fuentes directas y su competencia lingüística y filológica. Sólo un humanista como Juan de Valencia o su discípulo Bernardo de Alderete habría sido capaz de diseñar un programa iconográfico y simbólico para el retablo de la capilla de Santa Bárbara como el que existe en el sotobanco.

\section{UN PINTOR HUMANISTA.}

Todos estos datos enmarcan los paisajes de Santa Bárbara en un punto concreto de la Historia. Por un lado, deben situarse en un momento de plenitud del Humanismo en una pequeña ciudad provinciana como lo fue Málaga. Por otra parte, no debe tratarse de una fecha muy tardía, pues los postulados del Concilio de Trento hubieran impedido la representación de elementos paganos en un contexto religioso.

El límite de datación debe considerarse el primer cuarto del siglo XVII, si tenemos en cuenta la indumentaria del protagonista. Parece que éste viste calzas trusas, acuchilladas, que se emplearon en España durante el siglo XVI y hasta su prohibición por Felipe IV en las pragmáticas de 1623 y 1624, siendo sustituidas por los gregüescos o calzón, largos y holgados ${ }^{76}$.

Por otra parte, el mismo contenido de los paisajes y sus connotaciones, reducen las posibilidades de autoría: "Significativamente, la mayor parte de los

74 GONZÁLEZ SÁNCHEZ, V.: Caracteres de la sociedad malagueña del siglo XVI, Málaga, Diputación Provincial, 1987, págs. 47-48.

75 TALAVERA ESTESO, F. J.: Juan de Valencia..., págs. 24-25.

76 TEJEDA FERNÁNDEZ, M.: Glosario de términos de la indumentaria regia y cortesana en España. Siglos 
sepulcros con temas de difícil interpretación son de mano italiana. [...] La mayor independencia con respecto al poder eclesiástico y la exaltación del individuo desde una perspectiva meramente humana, propias del Renacimiento italiano, se reflejaron en su plástica funeraria" 77 .

Para los autores que defienden la datación del sotobanco en la segunda mitad del XVI, "estaríamos ante uno de los escasos ejemplos de esta temática y representarían una faceta bastante innovadora y moderna en el medio local que bien pudo ser consecuencia de la influencia de Arbassia en los pintores locales"78.

Cesare de Saluzzo, llamado l'Arbasia y conocido en España como César Arbasia, había llegado a Córdoba en 1577 con su amigo y colega Pablo de Céspedes, el Racionero, pintor erudito y destacado humanista en contacto los círculos artísticos y literarios de Italia, Sevilla y Granada. Ambos habían trabajado en Roma pintando al fresco la capilla Bonfili de la Santa Trinidad de Montes, correspondiendo a Céspedes las figuras humanas y a Arbasia los paisajes de fondo79. Además de este trabajo, Arbasia había realizado en solitario los frescos del claustro de este mismo convento y cuatro obras en la sala Ducal del Vaticano. Son estos últimos los que interesa destacar pues no sólo tratan el tema de la alabanza del mecenas a través de paisajes escatológicos sino que toman elementos del escudo del personaje a ensalzar, el dragón de Gregorio XIII Boncompagni, y los incluyen como alusiones mitológicas en las escenas pintadas ${ }^{80}$.

Estos paisajes con referencias al más allá, al jardín de las Hespérides y al mito de Proserpina no son ajenos a la obra de Arbasia en ningún momento de su carrera. En Roma lo había realizado tanto en el Vaticano como en la fachada frente a San Carlo en la hoy llamada "Vía del Corso", trabajo este último desaparecido y que realizó junto con Céspedes. En España lo pintó en el ciclo del palacio de los Bazán en el Viso del Marqués, en Ciudad Real.

Como paisajista César Arbasia había trabajado con Federico Zuccaro en la decoración interior de la cúpula de Santa María de las Flores de Florencia. Zuccaro había sido también maestro de Otto van Veen, uno de los ilustradores de la Tabla de Cebes y que tuvo por alumno a su vez a Rubens. También rea-

XVII y XVIII. Málaga, Universidad, 2006, págs. 126-127.

77 REDONDO CANTERA, M. J.: Op. Cit., págs. 228-229.

78 SAURET GUERRERO, T.: "Consideraciones...", pág. 22.

79 DÍAZ CAYEROS, P.: "Pablo de Céspedes entre Italia y España", Anales del Instituto de Investigaciones Estéticas, n 76, 2000, México D.F., Universidad Autónoma Nacional de México, pág. 22.

80 BLÁZQUEZ MATEOS, E. y SÁNCHEZ LÓPEZ, J. A.: Cesare Arbassia y la literatura artística del Renacimiento, Salamanca, Universidad, 2002, págs. 54-55. 
lizó Arbasia la decoración de la iglesia del Sagrario de Córdoba, esta vez siguiendo el programa iconográfico diseñado para él por Ambrosio de Morales ${ }^{81}$ quien a su vez había traducido el Pínax en 1534 y lo publicó en 1586.

¿Pudo César Arbasia haber pintado las tablas del sotobanco del retablo de la capilla de Santa Bárbara? La falta de documentación había justificado que las hipótesis continuaran siéndolo82. Pero en 1765 , los capellanes de Santa Bárbara establecieron un pleito con el Cabildo catedralicio por su negativa a pagar a la Fábrica lo que les correspondía por las contribuciones de ésta a la capilla. Para dar datos al abogado que defendía a los capitulares, Francisco Barbán de Castro, a la sazón Mayordomo de la Fábrica Mayor, tomó una serie de notas de los "Libros de Quentas de la Fábrica que existen en la Contaduría General del Obispado". En las mismas se anotan año por año los gastos de la Fábrica en la capilla de Santa Bárbara: limpieza, aceite para las lámparas, ornamentos, esteras, libros, breves... y su correspondiente costo desde 1554. En esa lista se puede leer: "En quentas del año 1578 se [...] componen ornamentos de Santa Bárbara. La reja 1500. La Pintura, 3000 ducados la pintó Cesar Arbasia y 3500 ducados la capilla mayor" 83 .

La noticia puede sin embargo ser confirmada y debatida. La fecha la repite Medina Conde quien también consultó los Libros de Fábrica: "Consta que desde antes de 1578 hasta después de 1589 estuvo pintando en esta Iglesia" 84 . Las cantidades son, sin embargo, desorbitadas para un trabajo tan pequeño. Son ciertas en cuanto que es lo que cobró el artista italiano según confirma Diego Fernández Romero, Mayordomo de Fábrica en 1582: tres mil ducados por su trabajo en la capilla del obispo fray Bernardo Manrique y tres mil quinientos por su obra en la capilla mayor 85 . Por tanto, si la fecha y las cifras que aparecían en los Libros de Fábrica son exactas, la explicación posible es que en una de dichas cantidades, probablemente la primera, se incluyan los honorarios de realización de este trabajo menor. Debe ser así por cuanto tampoco las rejas de la capilla pudieron costar ellas solas esos mil quinientos ducados que se indican, refiriéndose tal cantidad a la realización de todas las de la girola o de parte de ella.

\footnotetext{
81 SÁNCHEZ CANTÓN, F. J.: "El obispo Pazos, el cronista Morales y el pintor César Arbasia", Archivo Español de Arte y Arqueología, n 13, 1937, pág. 73.

82 SAURET GUERRERO, T.: Loc. Cit.

83 A. C. M. Leg. 586 , pieza 32.

84 MEDINA CONDE, C.: Op. Cit., pág. 51.

85 SÁNCHEZ LÓPEZ, J. A.: "Rex Martyrum. Sol Salutis. El palacio cristológico" en ARCOS VON HAARTMAN, E.: Retrato de la Gloria, Barcelona, Grupo Winterthur, 1999, pág. 49.
} 
En cuanto al estilo, existen coincidencias entre las obras de Arbasia y el pintor del sotobanco, pues el de Saluzzo "trabaja el paisaje como fondo decorativo y con un tratamiento de la decoración realizado a base de fino trazo dibujístico similar a los usados en las tablas del retablo de Santa Bárbara, que hacen pensar en esa participación, o influencia, del italiano en los citados paisajes" 86 .

Tanto por su contenido funerario como por su realización sobre tabla y no sobre lienzo, como lo están las obras de Juan Niño de Guevara y de Juan Coronado realizadas para la misma capilla en el siglo XVIII, cabe afirmar que los paisajes del sotobanco de la capilla de Santa Bárbara son, como proponen los investigadores de la primera hipótesis, de la segunda mitad del XVI. A ello contribuye no sólo la existencia de un círculo humanista en la Catedral de Málaga en torno a Juan de Valencia en el que cabe destacar al que fue su alumno hasta 1575, Bernardo de Alderete, quien a su vez trató el tema del más allá y las visiones en su obra ${ }^{87}$, sino también los contactos habituales entre César Arbasia y Pablo de Céspedes. Sólo en éste momento y con este material humano se podría haber realizado una obra semejante en la Catedral de Málaga. Parece 1578 una fecha razonable para que los postulados de Trento no afectaran todavía al programa de los paisajes. Sin embargo, continúa siendo una incógnita si el traslado de mobiliario o, al menos, el del retablo de Santa Bárbara, tuvo lugar entonces.

Esta elegía pintada en honor del canónigo Francisco del Pozo permaneció oculta, tras las aguas del Leteo, hasta que el siglo XXI bebió en las fuentes de Mnemósime y recordó el alma dormida. 